Article - Agronomy/Soil Science

\title{
Multiple Effect of Different Plant Growth Promoting Microorganisms on Beans (Phaseolus vulgaris L.) Crop
}

Venicios Vieira Gabre ${ }^{1}$

https://orcid.org/0000-0002-1557-3376

Wilson Story Venancio ${ }^{2}$

https://orcid.org/0000-0001-8188-1177

Breno Augusto Moraes ${ }^{1}$

https://orcid.org/0000-0002-9846-9020
Carolina Weigert Galvão ${ }^{1}$

https://orcid.org/0000-0002-8435-8944

Daniel Ruiz Potma Gonçalves ${ }^{1}$

https://orcid.org/0000-0003-2015-048X

Rafael Mazer Etto ${ }^{1^{*}}$

https://orcid.org/0000-0001-5138-7418

\section{Fernanda de Goes Furmam ${ }^{1}$}

https://orcid.org/0000-0002-6597-5824

${ }^{1}$ State University of Ponta Grossa, Microbial Molecular Biology Laboratory, Ponta Grossa, Paraná, Brazil; ${ }^{2}$ State University of Ponta Grossa, Department of Phytotechnics and Plant Health, Ponta Grossa, Paraná, Brazil.

Received: 2019.08.14; Accepted: 2020.03.30.

*Correspondence: mazeretto@uepg.br; Tel.: +55 42 2102-8140 (R. M. Etto)

\section{HIGHLIGHTS}

- Burkholderia sp. 10N6 inoculation performed similar to Rhizobium tropici in greenhouse experiment.

- Treatments behaved differently in greenhouse and field conditions.

- Inoculated treatments showed similar shoot dry biomass compared to nitrogen fertilization.

Abstract: We evaluated the effect of combined Rhizobium tropici, Trichoderma asperellum and plant growthpromoting rhizobacteria (PGPR) in beans crop. The hypothesis that strains of $T$. asperullum, $R$. tropici and PGPR combined could improve growth, biomass accumulation and beans yield was tested under greenhouse and field conditions. The treatments consisted of control, mineral nitrogen application and inoculation, isolated and associated with the following microorganisms: Rhizobium tropici, Bacillus subtilis, Trichoderma asperellum and Burkholderia sp. 10N6. Results were evaluated by shoot dry weight (SDW) and root dry weight (RDW), number of nodules and yield components. In greenhouse environment all the microorganisms behaved similarly, and the treatments inoculated with Burkholderia sp. $10 \mathrm{~N} 6$ (IBu) and $R$. tropici (IR) stood out regarding the production components. In field conditions the treatments IR and IRTBa presented the highest values of SDW and RDW. Our results suggest that inoculation with $R$. tropici, $T$. asperellum and PGPR may promote beans growth and bring benefits to shoot and root accumulation, increase the number of nodules as well as improve yield components, contributing to a sustainable agriculture.

Keywords: inoculation; bacteria; fungus; common bean. 


\section{INTRODUCTION}

Common bean (Phaseolus vulgaris L.) is a crop of great social and economic importance in Brazil. Besides being one of the main sources of protein for the population, it provides income for thousands of small farmers. Brazilian beans production in 2018 was about 2.97 million tons [1]. Among the different aspects related to cropping systems and beans production, $\mathrm{N}$ management stands out due to the high fertilizer costs [2]. Therefore, it is one of the main challenges, since insufficient fertilization rates may limit its potential and excessive rates are not only costly, but can promote negative environmental impact [3].

Biological nitrogen fixation (BNF) process can, at least partially, supply the requirements of this crop and ensure greater yield levels, up to $2500 \mathrm{~kg} \mathrm{ha}^{-1}[4,5]$. Several species of Rhizobium have been described as capable of creating nodules and, in most cases, fixing $\mathrm{N}_{2}$ with beans. In Brazil, $R$. tropici SEMIA 4077, 4080 and 4088 are the registered strains for use as inoculants in common beans (Normativa SDA13/2011).

Another group of beneficial soil microorganisms is represented by associative bacteria called plant growth-promoting rhizobacteria (PGPR) which are capable of promoting plant growth by means of several biological processes [6], including the production of several plant growth hormones as auxins [7], the capacity to induce plant resistance to diseases and stresses [8], to solubilize phosphate [9], and also biological nitrogen fixation $[7,10]$.

Co-inoculation of Rhizobium and PGPR in legumes has received more attention recently $[11,12,13]$. The co-inoculation of Pseudomonas sp. with Rhizobium leguminosarum brings positive effects on the cultivation of lentils, since it provides plant growth and nutrient uptake [14], increases nodulation in some crops, such as in pigeon pea [(Cajanus cajan (L.) Mill sp.)], with the co-inoculation of Pseudomonas fluorescens and Rhizobium sp. [15]. Besides, this combination presents positive effects on grain yield, as reported for beans, inoculated with Pseudomonas and Rhizobium [16].

The fungi genus Trichoderma has been exploited as biocontrol agent against a range of plant pathogenic fungi because it antagonizes a number of plant pathogens [17]. In addition, it has been widely used as plant growth promoter $[18,19]$. The combination of biocontrol agents and PGPR increases disease suppression [20], improves crop yields and facilitates nutrient uptake by plants [21] over individual inoculations. In this way, this study was undertaken to test the hypothesis that the combination of Trichoderma, Rhizobium and PGPR strains could improve growth, biomass accumulation and yield in beans. The hypothesis was tested under greenhouse conditions as well as field to monitor the effects of individual and combined inoculation of these organisms.

\section{MATERIAL AND METHODS}

\section{Inoculants and experimental design}

Common beans ( $P$. vulgaris L.) were inoculated in furrow with commercial products containing Rhizobium tropici SEMIA 4088, Bacillus subtilis QST 713 and Trichoderma asperellum SF 04 in the following concentration: $10^{9} \mathrm{CFU} / \mathrm{mL}, 10^{9} \mathrm{CFU} / \mathrm{mL}, 10^{9} \mathrm{CFU} / \mathrm{g}$, respectively. Besides, Burkholderia sp. 10N6, from PGPR bank of Microbial Molecular Biology Laboratory (State University of Ponta Grossa) was tested due to its capacity to fix nitrogen, produce AIA, protease, siderophore, and solubilize phosphate in vitro trials. $R$. tropici, B. subtilis and T. asperellum were applied at the following doses: $2.5 \mathrm{ml}, 2 \mathrm{ml}$ and $1 \mathrm{~g}$ per $\mathrm{kg}$ of seeds, respectively. Burkholderia sp. $10 \mathrm{~N} 6$ was applied at the dose of $2.5 \mathrm{~mL}$ per $\mathrm{kg}$ of seed after growing in liquid Digs medium [22] until the concentration of $10^{8} \mathrm{CFU} / \mathrm{mL}$. The bean seeds were chemically treated with Standak ${ }^{\circledR}$ Top (Piraclostrobin + Methyl Thiophanate + Fipronil) at a dose of $2 \mathrm{~mL}$ per $\mathrm{kg}$ of seeds.

Both experiments included two controls, (1) non-inoculated control (NI), and (2) non-inoculated control receiving $\mathrm{N}$-fertilizer $(\mathrm{NI}+\mathrm{N})$. In field experiment, plants received $150 \mathrm{~kg} \mathrm{~N} \mathrm{ha}^{-1}$ of urea in the $\mathrm{R} 5$ phenological stage (pre-flowering) and in the greenhouse experiment, received $0.30 \mathrm{~g} \mathrm{pot}^{-1}$ of urea at V4 (third open trifoliate). Beside the controls, the following treatments, were included: (3) Inoculated with $R$. tropici (IR), (4) Inoculated with $R$. tropici $+B$. subtilis (IRBa), (5) Inoculated with $R$. tropici $+T$. asperellum (IRT), (6) Inoculated with $R$. tropici + Burkholderia sp. (IRBu), (7) Inoculated with $B$. subtilis (IBa), (8) Inoculated with T. asperellum (IT), (9) Inoculated with Burkholderia $s p$. (IBu) and (10) Inoculated with $R$. tropici $+T$. asperellum $+B$. subtilis (IRTBa). The experiment was conducted under a complete randomized design in greenhouse and randomized block design in field conditions, totaling ten treatments. In greenhouse, twelve pots were cultivated per treatment and in field, four replicates of $18 \mathrm{~m}^{2}$ each. 


\section{Sites description and field management}

The greenhouse experiment was conducted from November of 2017 to January, 2018 in Ponta Grossa State University. Beans were grown in $8 \mathrm{~L}$ pots, using a mixture of sand and vermiculite (1:1) as substrate. All vessels received addition of macro and micronutrients as described by [23] and were irrigated before sowing. Bacteria inoculation was performed in furrow close to the seeds using micropipettes.

The field experiment was conducted from January to April 2018 at the Estação Experimental Agrícola Campos Gerais (EEACG), located in Palmeira - PR (2525'43, 50 "S, 50³'14.46" O), with elevation of 831 $\mathrm{m}$. Chemical and physical analysis of the $0-20 \mathrm{~cm}$ soil layer are showed in Table 1 . The soil is classified as medium texture Cambisol. There was no base fertilization at the time of beans sowing, since the area received $15 \mathrm{Mg} \mathrm{ha}^{-1}$ of sewage sludge in December 2017. The climate is classified as temperate $(\mathrm{Cfb})$, according to Köppen classification and during the experiment $662 \mathrm{~mm}$ accumulated as precipitation, with maximum temperature of $26.2^{\circ} \mathrm{C}$ in March and minimum of $15.6{ }^{\circ} \mathrm{C}$ in April.

Table 1. Chemical and physical properties of the soils $(0-20 \mathrm{~cm})$ before sowing.

\begin{tabular}{|c|c|c|c|c|c|c|c|c|c|c|c|c|c|}
\hline \multicolumn{11}{|c|}{ CHEMICAL } & \multicolumn{3}{|c|}{ PHYSICAL } \\
\hline $\mathrm{pH}$ & $(\mathrm{H}+\mathrm{Al})$ & $\mathrm{K}$ & $\mathrm{Ca}$ & $\mathrm{Mg}$ & $\mathrm{Al}$ & CEC & $\mathrm{T}_{\mathrm{CEC}}$ & BS & $\mathrm{MO}$ & $P$ & Clay & Silt & Sand \\
\hline $\mathrm{CaCl} 2$ & \multicolumn{7}{|c|}{$\mathrm{mmolc} \mathrm{dm}^{-3}$} & $\%$ & $\mathrm{~g} \mathrm{dm}^{-3}$ & $\mathrm{mg} \mathrm{dm}^{-3}$ & & $\mathrm{~g} \mathrm{~kg}^{-1}$ & \\
\hline 4.4 & 126 & 2.5 & 20 & 14 & 26.8 & 162.5 & 36.5 & 22.46 & 24 & 18 & 303 & 254 & 443 \\
\hline
\end{tabular}

CEC - Cation Exchange Capacity $(\mathrm{H}+\mathrm{Al}+\mathrm{Ca}+\mathrm{Mg}+\mathrm{K}) ; \mathrm{T}_{\mathrm{CEC}}-\mathrm{Ca}+\mathrm{Mg}+\mathrm{K} ; \mathrm{BS}-$ Base Saturation $(\mathrm{Tcec} / \mathrm{CEC}) \times 100$

The experimental plots were $2.25 \mathrm{~m}$ (width) $\times 8 \mathrm{~m}$ (length) and the seed lines were spaced $0.45 \mathrm{~m}$, with fifteen plants per meter. Inoculants were applied to furrows by direct spraying. The area was desiccated before sowing and before harvesting to standardize beans senescence. Herbicides and insecticides were used in all treatments, according to technical recommendations.

\section{Plant sampling and harvesting}

In the greenhouse experiment, three evaluations were performed, totaling four replicates for each evaluation. At V4, shoot dry weight (SDW) and root dry weight (RDW) were evaluated. At R6, SDW, RDW, number of nodules (NN) and their respective weight (NDW) were evaluated. At R9, the harvest was carried out, thus determining productivity per pot and yield components: number of pods per plant (PPL), number of grains per pod (GP) and weight of one thousand grains (WTG).

In field experiment, SDW and RDW at V4 and R6 were evaluated. The evaluations were performed on ten plants per plot. Harvesting was performed on $5.4 \mathrm{~m}^{2}$ per plot, and yield components PPL, GP and WTG were determined in two remaining meters per plot, by collecting ten plants.

\section{Statistical analyses}

Treatments differences in both experiments were tested trough analysis of variance (ANOVA) after normality, variance homoscedasticity and outlier's absence requirements check. When significance at $p<0.05$ was find, means were compared using Tukey test at $p<0.05$. To summarize the data variance, we performed a principal component analysis for each of the experiments. All analysis was performed using $R$ language $v$ 3.5.1 [24].

\section{RESULTS}

\section{Effect of PGPM inoculation on beans grown under greenhouse conditions}

Shoot dry weight (SDW) at V4 showed no statistical difference between treatments and at R6 the uninoculated and fertilized with mineral $\mathrm{N}(\mathrm{NI}+\mathrm{N})$ treatment was statistically higher than the control without inoculation $(\mathrm{NI})$ and co-inoculated treatments with $R$. tropici + B. subtilis (IRBa), R. tropici $+T$. asperellum $(\mathrm{IRT})$ and $R$. tropici $+T$. asperellum $+B$. subtilis $(\mathrm{IRTBa})($ Table 2). However, the treatments inoculated with R. tropici (IR), R. tropici + Burkholderia sp. 10N6 (IRBu), B. subtilis (IBa), T. asperellum (IT) and Burkholderia sp. $10 \mathrm{~N} 6(\mathrm{IBu})$ were statistically equal to the $\mathrm{NI}+\mathrm{N}$. For root dry weight (RDW), treatments IBa, IT and IBu presented the highest values at $\mathrm{V} 4$ (Table 2). In $\mathrm{R} 6$, only the $\mathrm{NI}+\mathrm{N}$ treatment stood out statistically from the 
others, presenting $2.42 \mathrm{~g}$ more than average treatments that received inoculation. For nodulation, there was no statistical difference between treatments (Table 2).

Table 2. Effect of inoculation with plant growth promoting microorganisms (PGPM) on shoot dry weight (SDW) and root dry weight (RDW) at stage V4 and SDW, RDW, nodule number (NN) and nodule dry weight (NDW) at stage R6 of common bean cultivated in greenhouse conditions.

\begin{tabular}{|c|c|c|c|c|c|c|}
\hline \multirow{3}{*}{ Treatment $^{a}$} & \multicolumn{2}{|c|}{ V4 } & \multicolumn{4}{|c|}{$\mathrm{R} 6$} \\
\hline & SDW & RDW & SDW & RDW & NN & NDW \\
\hline & \multicolumn{2}{|c|}{$g$} & \multicolumn{2}{|c|}{$g$} & $\mathrm{n}^{\circ} \mathrm{pl}^{-1}$ & $\mathrm{mg} \mathrm{pl}^{-1}$ \\
\hline $\mathrm{NI}$ & $1.58 \mathrm{a}$ & $0.675 a b$ & $6.74 \mathrm{~b}$ & $4.55 \mathrm{~b}$ & $3.00 \mathrm{a}$ & $0.00 \mathrm{a}$ \\
\hline $\mathrm{NI}+\mathrm{N}$ & $1.51 \mathrm{a}$ & $0.659 a b$ & $12.71 \mathrm{a}$ & $6.88 a$ & $2.00 \mathrm{a}$ & $0.00 \mathrm{a}$ \\
\hline $\mathrm{IR}$ & $1.58 \mathrm{a}$ & $0.721 a b$ & $10.01 \mathrm{ab}$ & $4.45 \mathrm{~b}$ & $33.75 \mathrm{a}$ & $61.0 \mathrm{a}$ \\
\hline IRBa & $1.83 \mathrm{a}$ & $0.781 \mathrm{ab}$ & $8.74 \mathrm{~b}$ & $4.35 \mathrm{~b}$ & $40.25 a$ & $75.0 \mathrm{a}$ \\
\hline IRT & $1.55 \mathrm{a}$ & $0.629 \mathrm{~b}$ & $8.60 \mathrm{~b}$ & $4.23 \mathrm{~b}$ & $54.50 \mathrm{a}$ & $164.0 \mathrm{a}$ \\
\hline IRBu & $1.79 \mathrm{a}$ & $0.804 a b$ & $10.63 \mathrm{ab}$ & $4.53 \mathrm{~b}$ & $45.25 \mathrm{a}$ & $120.0 \mathrm{a}$ \\
\hline $\mathrm{IBa}$ & $1.65 \mathrm{a}$ & $0.860 \mathrm{a}$ & $10.33 a b$ & $4.44 \mathrm{~b}$ & $42.75 \mathrm{a}$ & $86.0 \mathrm{a}$ \\
\hline IT & $1.73 \mathrm{a}$ & $0.850 \mathrm{a}$ & $10.00 \mathrm{ab}$ & $4.71 \mathrm{~b}$ & $47.25 \mathrm{a}$ & $58.0 \mathrm{a}$ \\
\hline $\mathrm{IBu}$ & $1.71 \mathrm{a}$ & $0.862 \mathrm{a}$ & $9.97 \mathrm{ab}$ & $4.73 \mathrm{~b}$ & $24.50 \mathrm{a}$ & $52.0 \mathrm{a}$ \\
\hline IRTBa & $1.71 \mathrm{a}$ & $0.726 \mathrm{ab}$ & $8.38 b$ & $4.21 \mathrm{~b}$ & $46.00 \mathrm{a}$ & $97.0 \mathrm{a}$ \\
\hline
\end{tabular}

a $\mathrm{NI}$ non-inoculated and without $\mathrm{N}$-fertilizer; $\mathrm{NI}+\mathrm{N}$ non-inoculated with $0.30 \mathrm{~g} \mathrm{pot}^{-1}$, IR inoculation with $R$. tropici SEMIA 4088, IRBa R. tropici + B. subtilis, IRT R. tropici + T. asperellum, IRBu R. tropici + Burkholderia sp. 10N6, IBa B. subtilis, IT T. asperellum, IBu Burkholderia sp. 10N6, IRTBa R. tropici $+T$. asperellum $+B$. subtilis. Data represent the means of three (V4 stage) and four (R6 stage) replicates and when followed by the same letter, within each column are not statistically different (Tukey, $p \leq 0.05$ ).

\section{Effect of PGPM inoculation on beans grown under field conditions}

In V4 the treatments inoculated with IR, R. tropici + B. subtilis (IRBa), IRT, IRBu, IBa and IRTBa presented the highest values of SDW and were statistically equal to each other. In R6, the treatments inoculated with IR, IRTBa, IRT and IRBu were statistically higher than the non-inoculated control (NI), presenting an increase of $67.3 \%, 63.7 \%, 62.5 \%$ and $61.8 \%$ respectively (Table 3 ). All treatments that received inoculation or co-inoculation were statistically equal to $\mathrm{NI}+\mathrm{N}$ treatment. However, $\mathrm{NI}+\mathrm{N}, \mathrm{IRBa}, \mathrm{IBa}$, IT and IBu treatments did not differ statistically from NI.

For RDW, in V4, IR and IRTBa treatments were statistically higher than $\mathrm{NI}$ treatment and $\mathrm{NI}+\mathrm{N}$ treatment. IRTBa co-inoculation provided an increase of $57.1 \%$ in relation to the $\mathrm{NI}$ and $49.1 \%$ in relation to $\mathrm{NI}+\mathrm{N}$, whereas only $R$. tropici inoculation presented $52.7 \%$ of root increase in relation to the $\mathrm{NI}$ and $44.9 \%$ compared to $\mathrm{NI}+\mathrm{N}$. In R6, only IRTBa co-inoculation showed statistical difference from $\mathrm{NI}$, presenting root growth of $47.8 \%$. The other inoculated treatments were statistically equal to IRTBa and NI (Table 3). 
Table 3. Effect of inoculation with plant growth promoting microorganisms (PGPM) on shoot dry weight (SDW) and root dry weight (RDW) at stage V4 and SDW, RDW at stage R6 of common bean cultivated in field conditions.

\begin{tabular}{|c|c|c|c|c|}
\hline \multirow{3}{*}{ Treatmenta $^{\mathrm{a}}$} & \multicolumn{2}{|c|}{ V4 } & \multicolumn{2}{|c|}{$\mathrm{R} 6$} \\
\hline & SDW & RDW & SDW & RDW \\
\hline & \multicolumn{2}{|c|}{$g$} & \multicolumn{2}{|c|}{$g$} \\
\hline $\mathrm{NI}$ & $14.18 \mathrm{bc}$ & $3.34 \mathrm{~cd}$ & $71.02 \mathrm{~b}$ & $15.51 \mathrm{~b}$ \\
\hline $\mathrm{NI}+\mathrm{N}$ & $12.31 \mathrm{c}$ & $3.52 \mathrm{bcd}$ & $107.00 \mathrm{ab}$ & $20.04 a b$ \\
\hline IR & $26.31 \mathrm{a}$ & $5.10 \mathrm{a}$ & $118.84 \mathrm{a}$ & $20.88 a b$ \\
\hline IRBa & $23.59 a b$ & $4.51 \mathrm{abc}$ & $101.53 \mathrm{ab}$ & $18.07 \mathrm{ab}$ \\
\hline IRT & $27.25 \mathrm{a}$ & $4.67 \mathrm{ab}$ & $115.41 \mathrm{a}$ & $17.98 a b$ \\
\hline IRBu & $18.84 \mathrm{abc}$ & $3.88 \mathrm{bcd}$ & $114.93 \mathrm{a}$ & $19.64 \mathrm{ab}$ \\
\hline $\mathrm{IBa}$ & $19.59 \mathrm{abc}$ & $4.32 \mathrm{abcd}$ & $106.75 \mathrm{ab}$ & $18.33 a b$ \\
\hline IT & $12.66 \mathrm{c}$ & $3.29 \mathrm{~d}$ & $105.08 \mathrm{ab}$ & $19.96 a b$ \\
\hline $\mathrm{IBu}$ & $15.3 \mathrm{bc}$ & $3.55 \mathrm{bcd}$ & $100.31 \mathrm{ab}$ & $19.85 a b$ \\
\hline IRTBa & $19.91 \mathrm{abc}$ & $5.25 \mathrm{a}$ & $116.26 \mathrm{a}$ & $22.93 \mathrm{a}$ \\
\hline
\end{tabular}

a $\mathrm{NI}$ non-inoculated and without $\mathrm{N}$-fertilizer; $\mathrm{NI}+\mathrm{N}$ non-inoculated with $150 \mathrm{~kg}$ of N ha ${ }^{-1}$, IRinoculation with $R$. tropici SEMIA 4088, IRBa $R$. tropici + B. subtilis, IRT $R$. tropici $+T$. asperellum, IRBu $R$. tropici + Burkholderia sp. 10N6, IBa B. subtilis, IT T. asperellum, IBu Burkholderia sp. 10N6, IRTBa R. tropici $+T$. asperellum + B. subtilis. Data represent the means of four replicates and when followed by the same letter, within each column are not statistically different (Tukey, $\mathrm{p} \leq 0.05$ ).

\section{Effect of PGPM inoculation on bean yield components}

The $\mathrm{NI}+\mathrm{N}$ treatment was statistically higher and accounted for the highest yield $(8.86 \mathrm{~g})$ of beans under greenhouse conditions, which can be explained by the higher number of pods per plant (PPL) (11.60), found in this same treatment (Table 4). The IR, IBa and IBu treatments were statistically higher than $\mathrm{NI}$, showing $2.84 \mathrm{~g}, 2.46 \mathrm{~g}$ and $2.38 \mathrm{~g}$ increment, respectively. Although the variables weight of thousand grains (WTG) and GP did not show statistical difference between the treatments, IBu was highlighted as presented the highest WTG value $(227.97 \mathrm{~g})$, which was $37.6 \%$ higher than $\mathrm{NI}+\mathrm{N}$ and $5.28 \%$ higher than standard IR treatment (Table 4).

In field, grain yield did not show statistical difference among treatments, however, the highest yields were found in IRT (3185.50 kg ha-1) and IBa (3152.64 $\left.\mathrm{kg} \mathrm{ha}^{-1}\right)$ treatments. The IBa treatment stood out regarding WTG and GP, however, it was not statistically different from the other treatments. PPL values of the IRT treatment were statistically higher than all other treatments, IRT treatment presented approximately 13 more pods per plant than uninoculated treatment (NI) (Table 4). 
Table 4. Effect of inoculation with plant growth promoting microorganisms (PGPM) on yield components in common bean cultivated in greenhouse and field conditions.

\begin{tabular}{|c|c|c|c|c|c|c|c|c|}
\hline \multirow{3}{*}{ Treatmenta } & \multicolumn{4}{|c|}{ Greenhouse } & \multicolumn{4}{|c|}{ Field } \\
\hline & PPL & GP & YIELD & WTG & PPL & GP & YIELD & WTG \\
\hline & $\mathrm{n}^{\circ} \mathrm{pl}^{-1}$ & $\mathrm{n}^{\circ}$ pod $^{-1}$ & $g$ & $g$ & $\mathrm{n}^{\circ} \mathrm{pl}^{-1}$ & $\mathrm{n}^{\circ}$ pod $^{-1}$ & $\mathrm{~kg} \mathrm{ha}^{-1}$ & $g$ \\
\hline $\mathrm{NI}$ & $5.6 \mathrm{bc}$ & $2.97 \mathrm{a}$ & $2.95 d$ & $165.65 \mathrm{a}$ & $12.95 \mathrm{c}$ & $4.59 \mathrm{a}$ & $2556.05 \mathrm{a}$ & $238.00 \mathrm{a}$ \\
\hline $\mathrm{NI}+\mathrm{N}$ & $11.6 \mathrm{a}$ & $3.84 \mathrm{a}$ & $8.86 \mathrm{a}$ & $214.58 \mathrm{a}$ & $21.35 a b$ & $4.63 \mathrm{a}$ & $3021.24 \mathrm{a}$ & $259.58 \mathrm{a}$ \\
\hline IR & $8.20 \mathrm{bc}$ & $3.58 \mathrm{a}$ & $5.79 \mathrm{~b}$ & $216.52 \mathrm{a}$ & $20.35 a b$ & $4.51 \mathrm{a}$ & $2824.39 \mathrm{a}$ & $242.10 \mathrm{a}$ \\
\hline IRBa & $6.60 \mathrm{bc}$ & $3.26 \mathrm{a}$ & $4.67 \mathrm{bcd}$ & $221.29 \mathrm{a}$ & $23.15 a b$ & $4.39 \mathrm{a}$ & $2616.73 \mathrm{a}$ & $233.00 \mathrm{a}$ \\
\hline IRT & $7.00 \mathrm{bc}$ & $3.40 \mathrm{a}$ & $4.58 \mathrm{bcd}$ & $195.30 \mathrm{a}$ & $25.08 \mathrm{a}$ & $5.36 \mathrm{a}$ & $3185.50 \mathrm{a}$ & $241.50 \mathrm{a}$ \\
\hline IRBu & $6.00 \mathrm{bc}$ & $3.20 \mathrm{a}$ & $3.63 \mathrm{~cd}$ & $191.00 \mathrm{a}$ & $21.68 a b$ & $4.97 \mathrm{a}$ & $2860.57 \mathrm{a}$ & $243.30 \mathrm{a}$ \\
\hline $\mathrm{IBa}$ & $8.60 a b$ & $3.18 \mathrm{a}$ & $5.41 \mathrm{bc}$ & $197.12 \mathrm{a}$ & $19.95 a b$ & $5.23 \mathrm{a}$ & $3152.64 \mathrm{a}$ & $267.38 \mathrm{a}$ \\
\hline IT & $5.00 \mathrm{c}$ & $3.25 \mathrm{a}$ & $3.39 \mathrm{~cd}$ & $214.03 \mathrm{a}$ & 17.4 bc & $4.58 \mathrm{a}$ & $2694.41 \mathrm{a}$ & $254.30 \mathrm{a}$ \\
\hline $\mathrm{IBu}$ & $7.40 \mathrm{bc}$ & $3.22 \mathrm{a}$ & $5.33 \mathrm{bc}$ & $227.97 \mathrm{a}$ & $20.43 a b$ & $4.60 \mathrm{a}$ & $2760.42 \mathrm{a}$ & $252.63 \mathrm{a}$ \\
\hline IRTBa & $5.40 \mathrm{bc}$ & $3.10 \mathrm{a}$ & $2.81 \mathrm{~d}$ & $172.07 \mathrm{a}$ & $16.75 b c$ & $4.18 \mathrm{a}$ & $2556.54 \mathrm{a}$ & $232.03 \mathrm{a}$ \\
\hline
\end{tabular}

a $\mathrm{NI}$ non-inoculated and without $\mathrm{N}$-fertilizer; $\mathrm{NI}+\mathrm{N}$ non-inoculated with $150 \mathrm{~kg}$ of N ha-1 in field and $0.30 \mathrm{~g} \mathrm{pot}^{-1}$ in greenhouse, IR inoculation with $R$. tropici SEMIA 4088, IRBa $R$. tropici + B. subtilis, IRT $R$. tropici + $T$. asperellum, IRBu R. tropici + Burkholderia sp. 10N6, IBa B. subtilis, IT T. asperellum, IBu Burkholderia sp. 10N6, IRTBa R. tropici $+T$. asperellum $+B$. subtilis. Data represent the means of three (V4 stadium) and four (R6 stadium) replicates and when followed by the same letter, within each column are not statistically different (Tukey, $p \leq 0.05$ ).

IRT and IBa treatments showed a yield increase of $24.63 \%$ and $23.34 \%$, respectively compared to control (NI). It is superior than the increase registered for $\mathrm{NI}+\mathrm{N}$ treatment, which was equivalent to $18.2 \%$ (Figure 1). The yield levels achieved in the experiment were higher than the average yield found for Paraná state, which was $1340 \mathrm{~kg} \mathrm{ha}^{-1}$ in the $2017 / 18$ season [25].

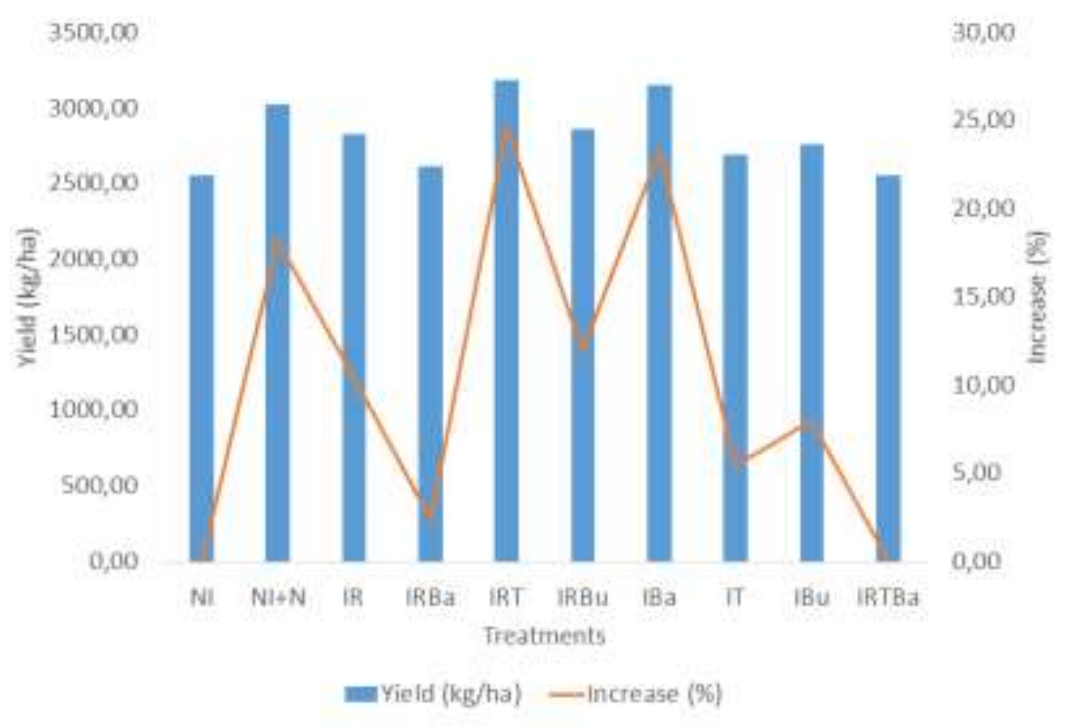

Figure 1. Effect of inoculation and co-inoculation in planting furrow on bean crop yield in the field. NI noninoculated and without $\mathrm{N}$-fertilizer; $\mathrm{NI}+\mathrm{N}$ non-inoculated with $150 \mathrm{~kg}$ of $\mathrm{N} \mathrm{ha}^{-1}$; IR inoculation with $R$. tropici SEMIA 4088; IRBa $R$. tropici + B. subtilis; IRT R. tropici + T. asperellum; IRBu R. tropici + Burkholderia sp. 10N6; IBa B. subtilis; IT T. asperellum; IBu Burkholderia sp. 10N6; IRTBa R. tropici + T. asperellum + B. subtilis. 
The principal component analysis summarized $80.31 \%$ of total variance for the greenhouse experiment and $71.83 \%$ for the field experiment (Figures 2 and 3 ). The greenhouse analysis showed all the microorganisms treatments behaving similarly, and the controls $(\mathrm{NI}+\mathrm{N}$ and $\mathrm{NI})$ deferring from the group. The variables were positively correlated and the IBu and IR based treatments presented higher values for yield components. In the field experiments, the variables were also positively related, but the correlations were weaker compared with greenhouse experiment, what may indicate higher random effects over data. The treatments $\mathrm{NI}$ and IRTBa differed from the others that composed a group.

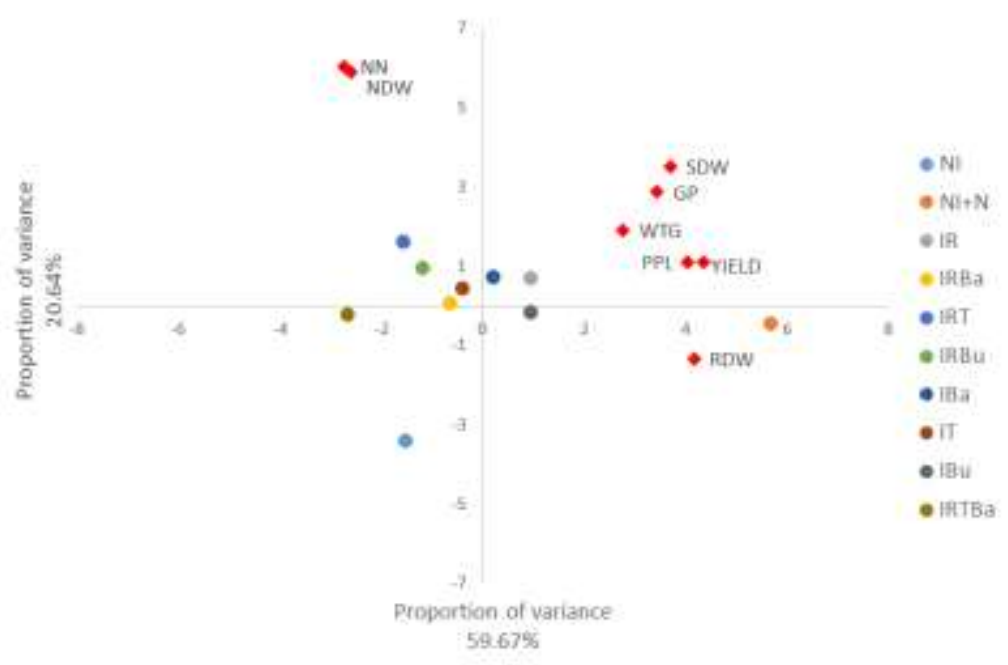

Figure 2. Principal component analysis (PCA) generated from shoot dry weight (SDW), root dry weight (RDW), weight of thousand grains (WTG), yield, number of pods per plant (PPL), number of grains per pod (GP), number of nodules $(\mathrm{NN})$ and nodule dry weight (NDW) under the condition of greenhouse in bean crop.

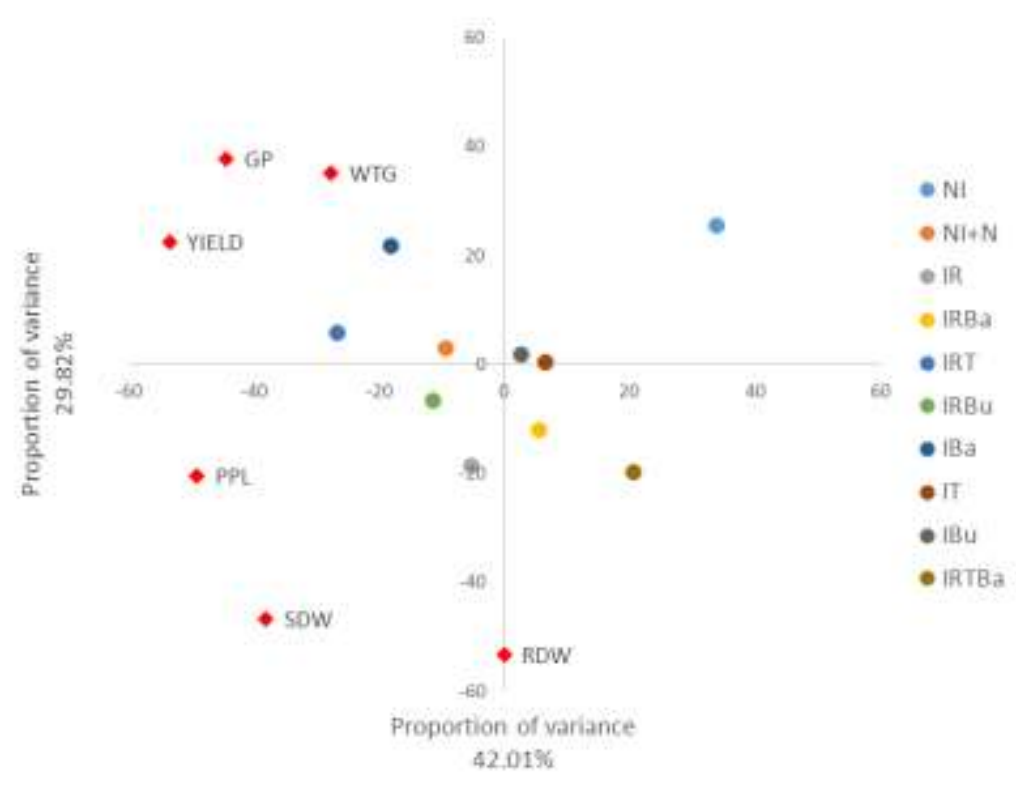

Figure 3. Principal component analysis (PCA) generated from shoot dry weight (SDW), root dry weight (RDW), weight of thousand grains (WTG), yield, number of pods per plant (PPL) and number of grains per pod (GP) under the condition of field in bean crop. 


\section{DISCUSSION}

The associations between microorganisms and plants have been studied for a long time, but its application in agriculture, partially or totally replacing chemical fertilizers, is still moderate. Common beans (Phaseolus vulgaris L.) are a cheap source of protein for growing world population, however, there are some concerns about the ability of biological nitrogen fixation to support plant growth and yield [26].

In greenhouse, the $\mathrm{NI}+\mathrm{N}$ treatment (nitrogen in cover) was highlighted in terms of grain yield in pots. This result may be associated with a higher accumulation of SDW and RDW in the greenhouse at R6 (Figure 2, Table 2). The yield is positively correlated with SDW, RDW, WTG, PPL and GP data, as shown in principal component analysis (Figure 2). In a recent study [27], the authors found higher yields, shoot dry weight, number of pods per plants and number of grains per plant when inoculation with $R$. tropici plus nitrogen fertilization at sowing $\left(20 \mathrm{~kg} \mathrm{ha}^{-1}\right.$ of $\left.\mathrm{N}\right)$ was used. However, the treatment that received inoculation only allowed a production of shoot dry weight equivalent to fertilized treatment, demonstrating that inoculation with rhizobium is equivalent to nitrogen fertilizer, however, with lower production cost. Other study [28] found results in SDW parameter: the control fertilized with mineral $\mathrm{N}$ was statistically higher than the treatment inoculated with $R$. tropici CIAT 899.

In the field experiment, at R6, all treatments that received PGPR inoculation were statistically equal to each other for SDW, however, IR, IRT, IRBu and IRTBa treatments were statistically higher compared to uninoculated treatment $(\mathrm{NI})$, showing that inoculation with PGPR improves beans' biomass accumulation. The authors [28] found similar responses with common bean in non-sterile soil: shoot biomass increased with co-inoculation with $R$. tropici CIAT $899+B$. elkanii 29 w when compared to plants inoculated only with $R$. tropici CIAT 899. However, co-inoculated plants did not differ statistically from the control, inoculated with $R$. tropici alone, which also happened in our study.

The use of PGPR with Rhizobium is justified by the ability to stimulate root growth, increasing the number of infection sites available for inoculated Rhizobium strains [29]. In addition, they are used as attempts to improve plant nodulation, BNF and nutritional status [30, 31, 32]. In our experiment, IRBu treatment presented the highest SDW at $\mathrm{R} 6$, being statistically equal to $\mathrm{NI}+\mathrm{N}$ treatment and the IRT treatment the highest $\mathrm{NN}$ and NDW in a greenhouse, demonstrating that the interaction between these microorganisms is favorable to beans development. Regarding the nodulation parameters, it is clear that the number of nodules (NN) and the weight of nodules (NDW) are correlated (Figure 2).

Nodules found in the $\mathrm{NI}, \mathrm{NI}+\mathrm{N}$, IBa, IT and IBu treatments might be occupied by nodulating bacteria from bean seeds or substrate, since used sand and vermiculite was not previously sterilized. A recent study [33] reported that Azospirillum was the fourth most abundant genus recovered from bacterial rRNA from bean seeds, concluding that Azospirillum indeed comprises a significant component of $P$. vulgaris seed microbiome. In addition, these authors found an abundance of $A$. brasilense within intercellular spaces of commom beans fibrous stem pith cells using confocal microscopy. In addition, [28] found Bradyrhizobium elkanii colonization in intracellular spaces of bean nodules, while colonization by $R$. tropici CIAT 899 was intracellular.

Interactions between rhizobia-legume-PGPR may contribute to rhizobia-legume symbiosis, as the use of PGPR induces legume nodules development, improves plant growth and BNF [34] and the use of Trichoderma controls phytopathogenic fungi and bacterial strains and produces plant growth metabolites [35]. Growth stimulation is perceived through increased biomass, productivity, stress resistance and increased nutrient absorption [36]. In greenhouse the IRT treatment was responsible for the largest NN, presenting approximately 20 more nodules than the IR treatment. In the field experiment, the same treatment presented the highest grain yield $\left(3185.50 \mathrm{~kg} \mathrm{ha}^{-1}\right)$, being superior to $\mathrm{NI}+\mathrm{N}$ treatment and resulting in $24.63 \%$ increase (Figure 1) compared to $\mathrm{NI}$ treatment. The co-inoculation of $R$. tropici and $T$. asperellum also influenced yield components, resulting in higher values of pod number and grain number per pod.

There was no increase of root dry weight parameter due to co-inoculation. Values of RDW of IRTBa coinoculation $(22.93 \mathrm{~g})$ was statistically equal to IR $(20.88 \mathrm{~g})$ at R6, in field conditions. However, IRTBa was statistically higher than NI, presenting an addition of $7.42 \mathrm{~g}$ of RDW. This result agrees with [37] study, which did not observe statistical difference in RDW between Rhizobium and PGPR co-inoculation and only Rhizobium. Similarly, [31] found no statistical difference between shoot and root dry weight of common bean inoculated with $R$. tropici CIAT 899 strain alone or with Paenibacillus polymyxa DSM 36 strain. The IR and IRTBa treatments presented the highest values of RDW and SDW demonstrating the existence of a positive correlation between these variables (Figure 3).

The treatments $\mathrm{NI}+\mathrm{N}$, IRT and IBa were responsible for the best results regarding bean yield, which is also positively correlated with WTG and GP (Figure 3). GP and WTG variables showed no significant differences among treatments under greenhouse and field conditions. For the PPL variable, in greenhouse, 
$\mathrm{NI}+\mathrm{N}$ treatment was statistically higher than the others, presenting 11.6 pods per plant. On the other hand, in the field, IRT treatment was statistically higher compared to others, with 25.08 pods per plant. [35] found some strains of Trichoderma that could stimulate early stages of growth in beans, potentially leading to the use of these strains as novel bioinoculants in agriculture with potential for increased crop yields. Greenhouse productivity was higher with $\mathrm{NI}+\mathrm{N}$ treatment. In field conditions, despite there was no statistical difference between treatments, comparing the treatments that received inoculation, IRT and IBa presented the highest yields, both numerically higher than $\mathrm{NI}+\mathrm{N}$ treatment. Other study [38] found maximum soybean yield with the co-inoculation of $B$. japonicum and $B$. subtilis over an uninoculated control. Also, [37] found extra abundant nodulation of the common bean with co-inoculation Bacillus megaterium + CIAT 899. Additionally, [39] reported an increase of shoot dry weight as a result of co-inoculation of common bean with Bacillus megaterium (M-3) strain and Rhizobium strain. In studies with other legumes, synergism between Bacillus and Bradyrhizobium in the rhizosphere has been shown to increase nodulation and plant biomass [34].

The greenhouse experiment behavior was not seen under field conditions (Figures 2 and 3). This may indicate that soil fauna in field conditions influenced the treatments. Similar results were reports by [28] who found less prominent response in non-sterile soil as a result of possible interactions with other soil microorganisms. The same was observed for the yield components, that presented higher variation in field conditions reflecting the greater environmental variation. Field experiments with plant growth promoting rhizobacteria (PGPR) usually show high variation [40]. Many factors like nitrogen fertilization, soil type, genetics, climatic conditions, can influence the development of crops and therefore, inoculation response [41].

In field conditions, the treatments did not show a clear pattern, however in greenhouse conditions IBu treatment was positively highlighted. In other study, [42] found that soil inoculation with Burkholderia sp. LD11 promoted biomass accumulation and improved instantaneous water use efficiency in greenhouse maize crop. Also, [43] reported that inoculation with $B$. fungorum UFLA 04-155 in beans promoted shoot dry matter and nutrient content compared to uninoculated plants not fertilized with nitrogen.

Many studies have considered combining rhizobia and PGPR strains to find sustainable biofertilizers as an alternative to chemical fertilizers [44]. To increase the inoculation efficiency, there is the need to better understand the interaction among the inoculated microorganisms and the host plant. Besides, it is essential to find genotypes more responsive to the plant-microorganism interaction to improve development and yield of various agricultural cultures.

\section{CONCLUSION}

Our results suggest that combined inoculation between $R$. tropici, T. asperellum and PGPR may promote beans growth and bring benefits to shoot and root accumulation, increasing the number of nodules as well as yield components. Although the greenhouse and field results did not converged, inoculation with Burkholderia sp. 10N6 in greenhouse seemed to promote beans growth. Further studies should be performed under different soil and climate conditions to confirm these results.

Acknowledgments: To CNPq, CAPES and Araucaria Foundation for their financial support. To Microbial Molecular Biology Laboratory and EEACG for their scientific support. Comercial AG for the availability of agricultural inputs.

Conflicts of Interest: The authors declare no conflict of interest. The funders had no role in the design of the study; in the collection, analyses, or interpretation of data; in the writing of the manuscript, or in the decision to publish the results.

\section{REFERENCES}

1. Instituto Brasileiro de Geografia e Estatística (IBGE) [Internet]. Levantamento Sistemático da Produção Agrícola: Indicadores IBGE; 2019 June 11 [updated 2019 July 22; cited 2019 July 22]. Available from: https://biblioteca.ibge.gov.br/visualizacao/periodicos/2415/epag_2019_maio.pdf_.

2. Cantarella H. Nitrogênio. In: Novais RF, Alvarez VVH, Barros NF, Fontes RLF, Cantarutti RB, Neves JCL, editor. Fertilidade de solos. Viçosa: Sociedade Brasileira de Ciência do Solo; 2007. p. 375-470.

3. Santos HG, Jacomine PKT, Anjos LHC, Oliveira VA, Oliveira JB, Coelho MR, Lumbreras JF, Cunha TJF. Sistema brasileiro de classificação de solos. 3rd ed. Rio de Janeiro: Embrapa Solos; 2013. 353 p.

4. Hungria M, Andrade DDS, Chueire LMDO, Probanza A, Guttierrez-Mañero FJ, Megías M. Isolation and characterization of new efficient and competitive bean (Phaseolus vulgaris L.) rhizobia from Brazil. Soil Biol Biochem. 2000 Oct; 32(11-12):1515-28.

5. Pelegrin R, Mercante FM, Otsubo IMN, Otsubo AA. Resposta da cultura do feijoeiro à adubação nitrogenada e à inoculação com rizóbio. Rev Bras Cienc Solo. 2009 Jan; 33:219-26. 
6. Chaparro JM, Sheflin AM, Manter DK, Vivanco JM. Manipulating the soil microbiome to increase soil health and plant fertility. Biol Fertil Soils. 2012 May; 48:489-99.

7. Ashraf MA, Rasool M, Mirza MS. Nitrogen fixation and indole acetic acid production potential of bacteria isolated from rhizosphere of sugarcane (Saccharum officinarum L.). Adv Biol Res. 2011 Jan; 5(6):348-55.

8. Wang $S$, Huijun W, Junqing $Q$, Lingli M, Jun L, Yanfei X, Xuewen G. Molecular mechanism of plant growth promotion and induced systemic resistance to tobacco mosaic virus by Bacillus spp. J Microbiol Biotechnol. 2009 Oct; 19(10):1250-8.

9. Rodriguez H, Gonzalez T, Goire I, Bashan Y. Gluconic acid pro- duction and phosphate solubilization by the plant growth-promoting bacterium Azospirillum spp. Naturwissenschaften. 2004 Oct; 91:552-5.

10. Döbereiner J, Pedrosa FO. Nitrogen-fixing bacteria in non- leguminous crop plants. Springer, Madison: Science Tech Publishers; Berlin: Springer-Verlag; 1987. $155 \mathrm{p}$.

11. Fatnassi IC, Chiboub M, Saadani O, Jebara M, Jebara SH. Impact of dual inoculation with Rhizobium and PGPR on growth and antioxidant status of Vicia faba L. under copper stress. C. R. Biologies. 2015 Apr; 338(4):241-54.

12. Korir H, Mungai NW, Thuita M, Hamba Y, Masso C. Co-inoculation effect of Rhizobia and plant growth promoting rhizobacteria on commom bean growth in a low phosphorus soil. Front Plant Sci. 2017 Feb; 8:141.

13. Ju W, Liu L, Fang L, Cui Y, Duan C, Wu H. Impact of co-inoculation with plant-growth-promoting rhizobacteria and rhizobium on the biochemical responses of alfafa-soil system in copper contaminated soil. Ecotoxicology and Environmental Safety. 2019 Jan;167:218-26.

14. Mishra PK, Bisht SC, Ruwari P, Joshi GK, Singh G, Bisht JK, Bhatt JC. Bioassociative effect of cold tolerant Pseudomonas spp. and Rhizobium leguminosarum-PR1 on iron acquisition, nutrient uptake and growth of lentil (Lens culinaris L.). European Journal of Soil Biology. 2011 Jan; 47:35-43.

15. Tilak KVB, Ranganayaki RN, Manoharachari C. Synergistic effects of plant-growth promoting rhizobacteria and Rhizobium on nodulation and nitrogen fixation by pigeon pea. European Journal of Soil Science. 2006 Jan; 57:6771.

16. Samavat S, Samavat S, Mafakheri S, Shakouri MJ. Promoting common bean growth and nitrogen fixation by the co-inoculation of Rhizobium and Pseudomonas fluorescens isolates. Bulgarian Journal of Agricultural Science. 2012 June; 18(3):387-95.

17. Chet I. Trichoderma: application, mode of action, and potential as a biocontrol agent of soil-borne plant pathogenic fungi. In: Chet I. (ed) Innovative Approaches to Plant Disease Control. New York: John Wiley and Sons; 1987. p. 137-60.

18. Harman GE. Myths and dogmas of biocontrol: Changes in perceptions derived from research on Trichoderma harzianum T-22. Plant Disease. 2000 Apr; 84(4):377-93.

19. Rabeendran N, Moot DJ, Jones EE, Stewart A. Inconsistent growth promotion of cabbage and lettuce from Trichoderma isolates. New Zealand Journal of Plant Protection. 2000; 53: 143-6.

20. Guetsky R, Shtienberg D, Elad Y, Fischer E, Dinoor A. Improving biological control by combining biocontrol agents each with several mechanisms of disease suppression. Phytopathology. 2002 Sept; 92(9):976-85.

21. Algawadi AR, Gaur AC. Associative effect of Rhizobium and phosphate solubilizing bacteria on the yield and nutrient uptake of chickpea. Plant Soil. 1988 Sept; 105:241-6.

22. Döbereiner J, Andrade VO, Baldani VL. D. Protocolos para Preparo de Meios de Cultura da Embrapa Agrobiologia. Seropédica: Embrapa Agrobiologia; 1999. 38 p.

23. EMBRAPA - Empresa Brasileira de Pesquisa Agropecuária. Métodos de Pesquisa em Fertilidade do Solo. Brasília; 1991. $390 \mathrm{p}$.

24. R Core Team. R: a Language and Environment for Statistical Computing [Internet]. Vienna: $R$ Foundation for Statistical Computing [updated 2018 Dec 20; cited 2018 Dec 20]. Available from: https://www.R-project. org/.

25. CONAB: Companhia Nacional de Abastecimento. Acompanhamento da safra brasileira: café. 2017; 4(1):1-98 [updated 2019 July 25; cited 2019 July 25]. Available from: http://www.conab.gov.br.

26. Hungria M, Nogueira MA, Araujo RS. Co-inoculation of soybeans and common beans with rhizobia and azospirilla: Strategies to improve sustainability. Biol Fertil Soils. 2013 Jan; 49(7): 791-801.

27. Barros RLN, De Oliveira LB, De Magalhães WB, Médici LO, Pimentel C. Interação entre inoculação com rizóbio e adubação nitrogenada de plantio na produtividade do feijoeiro nas épocas da seca e das águas. Semin Agrar. 2013 July; 34(4):1443-50.

28. Jesus EC, Leite RA, Bastos RA, Aragão OOS, Araújo AP. Co-inoculation of Bradyrhizobium stimulates the symbiosis efficiency of Rhizobium with common bean. Plant Soil. 2018 Feb; 425:201-215.

29. Cassán F, Perrig D, Sgroy V, Masciarelli O, Penna C, Luna V. Azospirillum brasilense Az39 and Bradyrhizobium japonicum E109, inoculated singly or in combination, promote seed germination and early seedling growth in corn (Zea mays L.) and soybean (Glycine max L.). Eur J Soil Biol. 2009 Jan; 45(1):28-35. 
30. Lee KD, Bai Y, Smith D, Han HS. Isolation of plant growth- promoting endophytic bacteria from bean nodules. Res J Agric Biol Sci. 2005 Jan; 1(3):232-6.

31. Figueiredo MVB, Martinez CR, Burity HA, Chanway CP. Plant growth-promoting rhizobacteria for improving nodulation and nitrogen fixation in the common bean (Phaseolus vulgaris L.). World J Microbiol Biotechnol. 2008 Nov; 24:1187-93.

32. Stajković O, Delić D, Josić D, Kuzmanović D, Rasulić N, Knežević-Vukčević J. Improvement of common bean growth by co-inoculation with Rhizobium and plant growth-promoting bacteria. Rom Biotechnol. 2011 Jan; 16:5919-26.

33. Malinich EA, Bauer CE. The plant growth promoting bacterium Azospirillum brasilense is vertically transmitted in Phaseolus vulgaris (common bean). Symbiosis. 2018 Feb; 76:97-108.

34. Thilak KVBR, Ranganayaki N, Manoharachari C. Synergistic effects of plant-growth promoting rhizobacteria and Rhizobium on nodulation and nitrogen fixation by pigeonpea (Cajanus cajan). Eur J Soil Sci. 2006 Jan; 57:67-71.

35. Hoyos-Carvajal L, Orduz S, Bissett J. Growth stimulation in bean (Phaseolus vulgaris L.) by Trichoderma. Biological Control. 2009 Dec; 51(3):409-16.

36. De Souza JT, Bailey BA, Pomella AWV, Erbe EF, Murphy CA, Bae H, Hebbar PK. Colonization of cacao seedlings by Trichoderma stromaticum, a mycoparasite of the witches' broom pathogen, and its influence on plant growth and resistance. Biological Control. 2008 July; 46(1):36-45.

37. Korir H, Mungai NW, Thuita M, Hamba Y, Masso C. Co-inoculation Effect of Rhizobia and Plant Growth Promoting Rhizobacteria on Common Bean Growth in a Low Phosphorus Soil. Front. Plant Sci. 2017 Feb; 8:1-10.

38. Tsigie A, Tilak KVBR, Saxena AK. Field response of legumes to inoculation with plant growth-promoting rhizobacteria. Biol Fertil Soils. 2011 Nov; 47(8):971-4.

39. Elkoca E, Turan M, Donmez MF. Effects of single, dual and triple inoculations with Bacillus subtilis, Bacillus megaterium and Rhizobium leguminosarum bv. phaseoli on nodulation, nutrient uptake, yield and yield parameters of common bean (Phaseolus vulgaris I. cv. 'elkoca-05'). Journal of Plant Nutrition. 2010 Oct; 33(14):2104-19.

40. Dobbelaere S, Croonenborghs A, Thys A, Ptacek D, Vanderleyden J, Dutto P, Labandera-Gonzalez C, CaballeroMellado J, Aguirre JF, Kapulnik Y, Brener S, Burdman S, Kadouri D, Sarig S, Pkon Y. Responses of agronomically important crops to inoculation with Azospirillum. Aust J Plant Physiol. 2001 Sept; 28(9):871-9.

41. Cassán F, Diaz-Zorita M. Azospirillum sp. in current agriculture: from the laboratory to the field. Soil Biol Biochem. 2016 Dec; 103:117-30.

42. Fan X, Hu H, Huang G, Huang F, Li Y, Palta J. Soil inoculation with Burkholderia sp. LD-11 has positive effect on water-use efficiency in inbred lines of maize. Plant Soil. 2015 Feb; 390: 337-49.

43. Oliveira-Longatti SM, Sousa PM, Marra LM, Ferreira PAA, Moreira FMSM. Burkholderia fungorum promotes common bean growth in a dystrophic oxisol. Ann Microbiol. 2015 Jan; 65:1825-32.

44. Diez-Mendez A, Menéndez E, García-Fraile P, Celador-Lera L, Rivas R, Mateos PF. Rhizobium cellulosilyticum as a co-inoculant enhances Phaseolus vulgaris grain yield under greenhouse conditions. Symbiosis. 2015 Dec; 67:135-41.

45. Prakamhang J, Tittabutr P, Boonkerd N, Teamtisong K, Uchiumi T, Abe M, Teaumroong N. Proposed some interactions at molecular level of PGPR coinoculated with Bradyrhizobium diazoefficiens USDA110 and $B$. japonicum THA6 on soybean symbiosis and its potential of field application. Applied Soil Ecology. 2015 Jan; 85:3849.

(C) 2020 by the authors. Submitted for possible open access publication under the terms and conditions of the Creative Commons Attribution (CC BY NC) license (https://creativecommons.org/licenses/by-nc/4.0/). 